Biografistyka Pedagogiczna

Rok 3 (2018) nr 1

ISSN 2543-6112; e-ISSN 2543-7399

DOI: 10.36578/BP.2018.03.14

Małgorzata Łobacz*

\title{
Sens przygodności człowieka na przykładzie życia Matki Elżbiety Róży Czackiej
}

\section{The Contingency of Human Life and its Meaning: Mother Elżbieta Róża Czacka}

\begin{abstract}
The article explores the meaning of suffering in human life based on the example of Mother Elżbieta Róża Czacka (1876-1961). Every person is a fragile and weak being. No one is ideal, perfect in all spheres of life, capable of undertaking unlimited challenges. The condition of being flawed and limited is therefore the condition of every human being. Disabled and sick people, those struggling with pain and difficulty therefore remind us of our human limitedness in a special way. Through their moral attitude, many of them teach us that weakness can be a creative force in human life. Mother Czacka, who found meaning in her suffering, is an example of a disabled person who devoted her life to others. She embraced her disability as a life task and vocation, a gift from God Himself.
\end{abstract}

Keywords: suffering, disability, contingency, personal development

Człowiekowi nie jest łatwo przyznać się - nawet przed samym sobą - do własnej słabości, ograniczoności. Kruchość istnienia wpisana została w naszą egzystencję od samego poczęcia i towarzyszy nam aż do śmierci, która jest szczególnym potwierdzeniem ludzkiej niemocy. Fakt bycia istotą przygodną doprowadza nas

* Małgorzata Łobacz - dr, adiunkt w Katedrze Biografistyki Pedagogicznej Instytutu Pedagogiki Katolickiego Uniwersytetu Lubelskiego Jana Pawła II, gkolomanska@wp.pl. 
do odkrycia innej cechy - jest nią potencjalność. A zatem świadomość własnej ułomności pomaga zrozumieć, że każda istota ludzka powołana jest do odkrywania pełni człowieczeństwa, urzeczywistnienia się jako osoba. Tę drogę - przejścia z niemocy, fizycznego ubóstwa, kalectwa do ujawnienia wewnętrznej siły - pokazuje życie Matki Elżbiety Czackiej. Będąc w pełni swojego życia, doświadczona została ciężką niepełnosprawnością sensoryczną i paradoksalnie odnalazła sens swojego istnienia w cierpieniu, poświęcając swoje życie dla innych.

Celem niniejszego artykułu będzie próba ukazania znaczenia ludzkich ograniczeń w dochodzeniu do pełni człowieczeństwa na przykładzie życia i działalności Założycielki Dzieła Lasek.

\section{Główne fakty z życia Róży Czackiej - Matki Elżbiety}

Róża Maria Czacka urodziła się 22 października 1876 r. w Białej Cerkwi (obecnie Ukraina). Była prawnuczką Tadeusza Czackiego - twórcy Liceum Krzemienieckiego. Ojcem jej był Feliks Czacki, matką zaś - Zofia z Ledóchowskich. Zofia Czacka "miała usposobienie raczej zimne i sztywny sposób bycia”. Po latach Matka Czacka napisała: „Dzieciństwo miałam dziwnie smutne. Matka moja była chorobliwie nerwowa, co stwarzało przykrą bardzo atmosferę w domu"2. Zofia Czacka była główną nauczycielką swojej córki, wspierały ją w tej roli niańki i wychowawczynie. Ojciec - pełen miłości i ciepła człowiek - często przebywał poza domem. Róża bardzo lubiła spędzać z nim czas, żywiła do niego „prawdziwy, niczym nie pomniejszony kult”3.

W 1882 r. Róża wraz z rodzicami wyjechała na stałe do Warszawy. W tym momencie rozpoczął się ważny etap w wychowaniu przyszłej Matki Czackiej. W tym samym domu mieszkała bowiem babcia dziewczynki - Pelagia z Sapiechów Czacka. „Wnuczka zawdzięczała babce rozwój swego życia modlitwy. [...] Poleciła jej nauczyć się na pamięć wiele modlitw, aby w razie potrzeby mogła obejść się bez książeczki do nabożeństwa. Nauczyła ją modlitwy myślnej i adoracji Najświętszego Sakramentu"4.

1 J. Stabińska, Matka Elżbieta Róża Czacka, Laski 1986, s. 29.

2 Archiwum Franciszkanek Służebnic Krzyża (dalej: AFSK), Notatki osobiste pisane na życzenie ojca Władysława Korniłowicza, 1927-1934 (14 IX 1927 - mps).

3 J. Stabińska, Matka Elżbieta, s. 29.

4 Tamże, s. 32. 
W dzieciństwie Róża martwiła się swoim wyglądem. Jej twarz miała męskie rysy, bardzo wydatny nos. „Miała jednak atuty urody - szlachetny wykrój niezwykle wrażliwych ust i piękny kształt oczu, była dość niska, ale zgrabnie, harmonijnie zbudowana [...] ciemno-szatynowe włosy spadały lokami za pas, twarzyczka uderzała śliczną cerą"5. Wyróżniała się wysokim poziomem intelektualnym i duchowym. Podobała się mężczyznom, choć we wspomnieniach jej bliskich nie ma wzmianki o staraniach o rękę Róży.

Rodzina - szczególnie ojciec - dbał o wszechstronne wykształcenie Róży. Była to znajomość języków: francuskiego, angielskiego, niemieckiego i rosyjskiego. Uczyła się literatury francuskiej, pobierała lekcje tańca i muzyki. Wyróżniała się znakomitym słuchem muzycznym, dobrze śpiewała i grała na fortepianie, uprawiała też jazdę konną.

Nie interesowało jej życie światowe, bywanie na salonach, uczty i przepych. W przyszłości - odnosząc się do takich sytuacji w swoim życiu - powie: „Życiem światowym żyłam dużo i miałam do niego wstręt - do «cukrzenia», do dyplomacji"6. Przeżywając najpiękniejsze lata swojego życia - utraciła wzrok. Z perspektywy czasu zwierzyła się jednej siostrze: „Jaki Pan Jezus jest dobry, kiedy najbardziej świat mi się podobał, kiedy zaczęłam do niego lgnąć, zabrał mi wzrok"7.

Róża Czacka od dzieciństwa miała problemy ze wzrokiem, choroba oczu była w jej rodzinie dziedziczna. Wokół utraty wzroku Matki Czackiej krąży wiele legend ${ }^{8}$. Przełomowym momentem był z pewnością upadek z konia, na skutek którego doszło do odklejenia siatkówek. Resztki wzroku utraciła w 1898 r., mając 22 lata.

Istotnym faktem w biografii Matki Elżbiety Róży Czackiej jest moment wizyty u okulisty - dr Bolesława Ryszarda Gepnera - która nadała kierunek jej dalszemu życiu: „Niechaj pani nie pozwoli wozić się od jednej sławy zagranicznej do drugiej. Tu nie ma nic do zrobienia, stan wzroku jest beznadziejny. Niech pani zajmie się niewidomymi, którymi w Polsce nikt się nie zajmuje" ${ }^{\prime \prime}$.

5 Tamże, s. 34.

6 Przemówienia do sióstr, 15 XII 1941 - J. Stabińska, Matka Elżbieta, s. 38.

7 Tamże, s. 38.

8 Wymienia się tu m.in. intensywne czytanie w późnych wieczornych godzinach przy lampie naftowej, skutki dymu podczas przeżytego pożaru czy wpatrywanie się w słońce.

9 J. Stabińska, Matka Elżbieta, s. 40. 
Od tej pamiętnej wizyty Róża podejmowała się różnych zajęć domowych, a szczególnie dużo czasu poświęcała modlitwie. To życie wewnętrzne, rozmodlenie, powierzenie swojego kalectwa Bogu zapewniło jej „dar mocy, który na całe życie uczynił ją niewiastą mężną"10. Kolejne dziesięć lat przyszła Matka Czacka poświęciła na usprawnienie swojego życia doświadczonego niepełnosprawnością, uczyła się samodzielności. Ponadto opanowała alfabet Braille’a, poznała najnowsze osiągnięcia nauki o niewidomych, odbyła wiele podróży po Europie (m.in. do Francji, Austrii, Szwajcarii).

Na fundamencie doświadczeń zdobytych podczas dziesięciu ostatnich lat powołała w $1911 \mathrm{r}$. Towarzystwo Opieki nad Ociemniałymi. Dzięki tej instytucji powstały w Warszawie: ochronka, szkoła powszechna, warsztaty, biblioteka brajlowska oraz tzw. patronat, obejmujący na terenie miasta dorosłych niewidomych i ich rodziny. Lata pierwszej wojny światowej Czacka spędziła w Żytomierzu. Wtedy też zrodziła się myśl o podjęciu życia zakonnego oraz o powołaniu nowego zgromadzenia zakonnego, które służyłoby ludziom niewidomym. W 1917 r. przyjęła habit franciszkański i złożyła śluby wieczyste w III Zakonie św. Franciszka ${ }^{11}$.

W maju 1918 r. wróciła do Warszawy już jako siostra Elżbieta. Po uzyskaniu koniecznych pozwoleń przyjmowała kandydatki do nowego zgromadzenia, które od 1 grudnia 1918 r. zaczęło istnieć jako Zgromadzenie Sióstr Franciszkanek Służebnic Krzyża. Jego charyzmatem stała się służba ludziom niewidomym i wynagradzanie za duchową ślepotę świata. Opiekunem duchowym Zgromadzenia i całego Dzieła został ks. Władysław Korniłowicz ${ }^{12}$.

W 1922 r. Matka Czacka otrzymała dar w postaci kilku mórg ziemi w Laskach i tym samym rozpoczęła budowę zakładu dla niewidomych. W to miejsce stopniowo zostały przeniesione placówki dla niewidomych dzieci - szkoła i warsztaty. Tu także powstał dom macierzysty Zgromadzenia Franciszkanek Służebnic Krzyża - założonego przez Matkę Elżbietę Różę Czacką ${ }^{13}$.

10 Tamże, s. 41.

11 Towarzystwo Opieki nad Ociemniałymi w Laskach, http://www.laski.edu.pl/pl/ ludzie-lasek?opt_4782_article_id=4923, dostęp: 3.07.2017.

12 Tamże.

13 J. Kuczyńska-Kwapisz, Wkład Matki Elżbiety Róży Czackiej w rozwój tyflologii w kontekście współczesnej recepcji jej myśli, Warszawa 2011, s. 22. 
Do momentu wybuchu drugiej wojny światowej, Laski kierowane przez Matkę Czacką stały się nowoczesną placówką. W tym miejscu niewidomi wychowankowie zdobywali wykształcenie podstawowe i zawodowe, które pozwalało im na samodzielne i niezależne finansowo życie, a często przywracało im osobową godność.

We wrześniu 1939 r., w czasie bombardowania Warszawy, Matka Elżbieta została ranna w głowę i straciła oko. Mimo dodatkowego trudu, bólu i cierpienia - po powrocie do Lasek - kierowała odbudową zakładu. W 1950 r. rozpoczęła się trwająca do śmierci choroba Róży Czackiej. W tym okresie kierownictwo przekazała swojej następczyni i wspierała dzieło modlitwą i ofiarą cierpienia. Matka Elżbieta Róża Czacka zmarła w opinii świętości 15 maja 1961 r. w Laskach. Jej grób znajduje się na cmentarzu usytuowanym na terenie Ośrodka Szkolno-Wychowawczego w Laskach ${ }^{14}$.

\section{Kruchość istnienia - udziałem życia każdej istoty ludzkiej}

Każdy człowiek stanowi kruchą egzystencję, jest istotą słabą, „którą unicestwić może przypadek biologiczny, wiatr historii czy zwykłe, żmudne działanie czasu"15. Doświadczenie egzystencjalnej ograniczoności wskazuje na fakt przygodności zakorzenionej w strukturze człowieka. Przygodność to kategoria metafizyczna akcentująca niekonieczność, utracalność, wadliwość oraz niedoskonałość bytu ludzkiego ${ }^{16}$.

Kruchość istnienia dotyka każdego z nas w wielu sferach. „Zmysły nasze nie chwytają nic krańcowego; zbyt wielki hałas nas ogłusza; zbytnie światło oślepia, zbytnia odległość i zbytnia bliskość przeszkadza wzrokowi"17. To dowodzi z kolei, że w pewnych sferach istoty ludzkie ustępują niektórym gatunkom zwierząt. Człowiek jest istotą ograniczoną, choć często trudno mu jest do tego się przyznać, także przed samym sobą.

14 Tamże, s. 23.

15 W. Chudy, W łupinie orzecha, czyli filozofia bez przesady, Marki-Struga 1992, s. 64

16 Tenże, Sens filozoficzny kondycji człowieka niepełnosprawnego, w: Osoba niepetnosprawna i jej miejsce w społeczeństwie, red. D. Kornas-Biela, Lublin 1988, s. 109.

17 B. Pascal, Myśli, tłum. T. Żeleński (Boy), Warszawa 1989, s. 66. 
Nie trzeba huku dział, aby pogmatwać jego myśli, wystarczy szelest chorągiewki na dachu albo skrzyp krążka. Nie dziwcie się, jeśli w tej chwili nie rozumuje dobrze: mucha brzęczy mu koło uszu; to dość by go uczynić niezdolnym do roztropnego myślenia. Jeśli chcecie, aby zdołał odkryć prawdę, wypędźcie to zwierzę, które trzyma w szachu jego rozum i mąci tę potężną inteligencję władnącą miastami i królestwami ${ }^{18}$.

Awicenna pojęcie przygodności wyjaśnia, wskazując na różnicę między istotą a istnieniem. Rozwijając tę definicję, istotę rozumiemy jako zbiór jakości-potencjalności, które, choć przynależą osobie, nie są nią samą. Człowiek jako osoba może dokonać refleksji nad nimi i zdystansować się wobec nich (aspekt transcendencji). Osoby bowiem „mają swą istotę, nie są bez reszty pogrążone w swym sposobie bycia. Przygodność natomiast jest rozumiana jako przygodność istnienia"19.

Fakt bycia bytem nie w pełni uaktualnionym, potencjalnym oraz ograniczoności w realizacji posiadanych możliwości w bezpośredni sposób świadczą o przygodności ludzkiego istnienia. To bytowe wybrakowanie człowieka dotyczy różnorodnych sfer: poznawczej, wolitywnej, daje o sobie znać w dziedzinie człowieka jednostkowego oraz w życiu społecznym ${ }^{20}$. Zjawisko słabości człowieka szczególnie widoczne jest w odniesieniu do fenomenu cierpienia. Chorzy, osoby z niepełnosprawnością, niewidomi, niesłyszący, przykuci do wózka czy łóżka, każdego dnia doświadczają swej przygodności.

Nie ma człowieka, który byłby idealny, w każdej sferze życia doskonały, zawsze sprawny, zdolny podejmować nieograniczone niczym wyzwania. Brakowość i ograniczenie, to cechy, które odnajduje w sobie każdy byt ludzki. W sposób szczególny wkomponowane są w przygodność, kruchość i okaleczalność bytową wartość zdrowia i życia ludzkiego. „Kto dzisiaj wydaje się zdrowy, może w sobie nosić ukrytą chorobę, może jutro ulec nieszczęściu i trwałemu kalectwu. Wszyscy jesteśmy pielgrzymami, droga nie jest długa, dla każdego kończy się śmiercią"21.

18 Tamże, s. 75-76.

19 R. Spaemann, Osoby. O różnicy między czymś a kimś, tłum. J. Merecki, Warszawa 2001, s. 89.

20 W. Chudy, Powołanie osoby niepetnosprawnej w nauczaniu papieża Jana Pawła II, w: Osoba niepełnosprawna i jej miejsce w społeczeństwie, red. D. Kornas-Biela, Lublin 1988, S. 129.

21 Jan Paweł II, Byłem upośledzony i przyszliście mi z pomoca, Osnabruck 16 XI 1980, Anioł Pański, „L' Osservatore Romano”, 1980, nr 31 (11) s. 4. 
Rozpoznanie i przeżycie przez osobę ludzką własnej brakowości stymuluje ją do szukania wartości absolutnych. Ponadto „doznanie swojej niewystarczalności bytowej pociąga człowieka w kierunku poszukiwań obiektywnych i stabilnych wymiarów bytu" ${ }^{\prime 22}$. Kruchość bytowania związana jest zatem z szansą rozwoju, co Karol Wojtyła wyraził w słowach: „Każdy byt, który musi dochodzić do własnej pełni, który podlega aktualizacji - jest przygodny"23. Możliwość bycia dobrym lub złym oraz idące za tym silnie odczuwane konsekwencje, doskonalące lub destruujące człowieka, świadczą o szczególnej wartości ograniczoności osoby. Wynika stąd, iż życie i szczęście każdego z nas zależy od spełnianych czynów ${ }^{24}$. Te zaś, gdy kierowane są miłością, wyzwalają ludzką kreatywność, przyczyniając się tym samym do rozwoju osoby.

Paradoksalnie doświadczenia słabości i ułomności ludzkiej mogą przyczyniać się do rozwoju osobowego człowieka. Nie jest to zadanie łatwe, wymaga akceptacji i aktywnej postawy wobec własnych ograniczeń - jak pisze Adam Rodziński - „cierpienie jest pracą"25. Jest również wyrazem transcendencji człowieka wobec jego braków materialnych i niematerialnych. Dzięki niej możliwym staje się odkrycie niezmiennych struktur bytowych w otwarciu na rzeczywistość nadprzyrodzoną. Świadomość ich istnienia nadaje sens życiu człowieka w horyzoncie przygodności.

O prawdziwej wielkości i autentycznym bogactwie człowieka świadczy więc poznanie i zrozumienie jego ograniczeń. Osoba ludzka o tyle jest wewnętrznie bogata, o tyle wielka, o ile zdolna jest przyznać się do swojej niemocy. Siła człowieka jest zatem ściśle wkomponowana w jego bezsilność. Każdy z nas jest w jakiś sposób niesprawny. Ową fundamentalną niepełnosprawność natury ludzkiej jesteśmy w stanie zrozumieć wówczas, gdy przekraczamy poziom powierzchownych pobudzeń, przestajemy być „wiecznym dzieckiem” i spotykamy się z ciężarem życia ${ }^{26}$.

22 W. Chudy, Powołanie osoby niepełnosprawnej w nauczaniu papieża Jana Pawła II, S. 129-130.

23 K. Wojtyła, Osoba i czyn oraz inne studia antropologiczne, Lublin 1994, s. 199.

24 A. Szostek, Wokó godności, prawdy i miłości, Lublin 1998, s. 98; też K. Wojtyła, Osoba i czyn, s. 198.

25 A. Rodziński, Na orbitach wartości, Lublin 1998, s. 282.

$26 \mathrm{~W}$ Chudy, Sens życia a sens trudu, w: Osoby niepełnosprawne $w$ życiu społeczeństwa i Kościoła, Katowice-Ruda Śląska 2003, s. 45. 
Współcześnie ludzie na ogół unikają świadomości własnej kruchości i ograniczoności bytowej poprzez ucieczkę do różnorodnych ideologii postulujących postawę pragmatyzmu, konsumpcjonizmu czy też hedonistycznego stylu życia ${ }^{27}$. Dlatego spotkanie z osobą niepełnosprawną stanowi ważne doświadczenie uświadamiające egzystencjalną kruchość każdej osoby ludzkiej. Zrozumienie zaś własnej słabości stanowi jedyną drogę do szczerej pomocy potrzebującym. Ludzie z niepełnosprawnością dalecy są bowiem od lansowanych współcześnie relatywnych wartości, jak: konsumpcjonizm, spryt życiowy, zaszczyty, stanowiska, prestiż. Oni wybierają proste wartości, ale zarazem najwyższe, autoteliczne: uczą zaufania, bezinteresowności, szczerości. Głębsza refleksja nad osobami niepełnosprawnymi odsłania prawdę uświadamiającą pozostałym ludziom, iż osoby chore i niepełnosprawne, poprzez przeżywane cierpienie, otrzymały szansę na „wyższe spełnienie osobowe” w społeczeństwie i od nich wymagany jest większy trud niż od przeciętnego człowieka. Ten rodzaj dodatkowego życiowego bagażu wzbogaca zarówno potrzebujących opieki, jak i tych, którzy wchodzą w relacje z cierpiącymi. Taki stan rzeczy winien wyzwalać postawy pełne bezinteresowności i bohaterstwa. Ucieczka od osób doświadczających cierpienia lub - w imię humanitaryzmu i majestacie prawa - pozbawianie ich życia świadczy o lęku i ucieczce współczesnych przed tym, co trudne, wymagające i niewygodne.

Refleksyjne i uważne „zastanowienie się nad parą wartości: trudność łatwość - w kontekście życia ludzkiego przekonuje nas o zasadniczym błędzie postawy ucieczki od trudu. [...] Albowiem samo życie jest trudne. Najważniejsze jego przejawy łączą się z wysiłkiem i cierpieniem"28. Świadomość własnych braków i niedoskonałości nie zatrzymuje osoby ludzkiej na powierzchni przemijających dóbr, lecz uzdalnia do odkrywania prawdziwych wartości. Świadomość egzystencjalnej kruchości człowieczeństwa człowieka umożliwia przyznanie się do własnej przygodności, co w dobie globalizacji jest wyjątkową cnotą. Matka Elżbieta Róża Czacka wielokrotnie podkreślała, że sens cierpienia zrozumieć można przede wszystkim na drodze wiary: „Świat obecny pogański nie rozumie racji cierpienia i buntuje się przeciwko niemu nie znajdując na nie lekarstwa... Ludzie obecnych czasów po większej części nie umieją cierpieć i dlatego jest

27 Tenże, Powołanie osoby niepełnosprawnej w nauczaniu papieża Jana Pawła II, s. 130. 28 Tenże, Sens życia a sens trudu, s. 45. 
im źle"29. Zanurzona w cierpieniu, potwierdziła, że sens życia człowiek może odkryć tylko wtedy, gdy z pokorą przyzna się do swojej osobowej przygodności i z odwagą podejmie trud życiowy.

\section{Sens przygodności miarą sensu życia założycielki Franciszkanek Służebnic Krzyża}

Wszelkie uszkodzenie, niepełnosprawność którejś części ludzkiego ciała bądź też niepełnosprawność któregoś z narządów nie powodują żadnych zmian statusu ciała jako całości - jest to nadal ciało osoby ludzkiej. Słaba kondycja organizmu, określone defekty w ciele, nawet bardzo głębokie, „nie ujmują w niczym człowieczeństwa ludzkiej cielesności" ${ }^{30}$. Przykładem jest tu niewątpliwie życie i działalność niewidomej Założycielki Zgromadzenia Franciszkanek Służebnic Krzyża.

Matka Czacka swoje kalectwo przyjęła jako zadanie i powołanie życiowe, otrzymane od samego Boga, który zapragnął z jej udziałem realizować wielkie dzieło swego miłosierdzia wobec najsłabszych, pokrzywdzonych przez los, jakimi są osoby niewidome. Dlatego zdecydowała się nie tylko sama żyć godnie i aktywnie w nowej rzeczywistości, ale także zająć się innymi niewidomymi, szczególnie dziećmi ${ }^{31}$.

Matka Elżbieta Róża Czacka doświadczyła w swoim życiu wiele cierpienia zarówno fizycznego, jak i duchowego. Były to m.in. pozbawienie wzroku, liczne umartwienia, życie w wielkim ubóstwie, operacyjne usunięcie oka, choroba nowotworowa, przez ostatnie dziesięciolecie swojego życia (po wylewie) nie mogła mówić i nie wstawała z łóżka, przeżywała także ciemną noc duszy. Cierpienie jest tajemnicą, samo w sobie nie jest ani dobre, ani wartościowe. „[...] intencją cierpienia jest zniszczenie człowieka - zniszczenie fizyczne i moralne.

29 AFSK, Dyrektorium Zgromadzenia Sióstr Franciszkanek Służebnic Krzyża (c. XXIX 23 III 1928 - mps).

30 A. Bartoszek, Niepełnosprawność osób jako wyzwanie moralne, w: Osoby niepełnosprawne w życiu Kościoła i społeczeństwa, red. A. tenże, D. Sitko, Katowice-Ruda Śląska 2003, s. 63-89; D. Szarkowicz, Osoby niepełnosprawne w społeczeństwie. Integracja czy zagrożenie wykluczeniem?, w: Marginalizacja w problematyce pedagogiki społecznej i praktyce pracy socjalnej, red. K. Marzec-Holka, Bydgoszcz 2005, s. 74.

31 T. Naumiuk, Duch miłosierdzia w życiu sługi Bożej matki Elżbiety Róży Czackiej, „Brat”, 2016, nr 11, s. 10. 
I w tym sensie cierpienie nie uszlachetnia. Wiedzą to wszyscy ci, którzy bardzo cierpią”; wiedziała to Matka Czacka, która sama twierdziła, że „ślepota jest ciężkim kalectwem. Nie pomniejszała dotkliwości braku wzroku"32. W swoim Dyrektorium określiła cierpienie jako „wstrętne naturze człowieka”, dodając zarazem, że „bez niego nie może być mowy o świętości”33. A zatem cierpienie samo w sobie jest brakiem czegoś, co powinno być naszym udziałem: zdrowia, sprawności, kondycji fizycznej, dobrego samopoczucia itd. Człowiek cierpi z powodu określonego niedostatku. Pozbawiony bowiem jest jakiegoś dobra, którego zabrakło, stanowi wstrząs, zwłaszcza gdy narusza jego życie ${ }^{34}$.

Jednak to właśnie na drodze cierpienia człowiek jest w stanie doświadczyć transcendencji swojego człowieczeństwo. Jan Paweł II pisze obrazowo o przynależności cierpienia do „transcendencji człowieka”, ponieważ stanowi ono silny impuls i tajemnicze wezwanie do „przerastania siebie”. Kierunek tego wzrastania stanowi dojrzała miłość, a drogą do jej realizacji na drodze cierpienia jest wypracowywanie cnót ${ }^{35}$. Tadeusz Gadacz, podejmując refleksję na temat cierpienia, mówi o „paradoksie cierpienia” jako jedynej sytuacji, która zawierając w sobie „zło" - m.in. wynikające z bólu, poczucia niesprawiedliwości, odrzucenia, może przynosić dobre owoce ${ }^{36}$. Czytelnym tego dowodem jest życie Róży CzackiejMatki Elżbiety. Fundamentalną rolę we właściwym odczytaniu sensu cierpienia odegrała wiara w Boga i odkrycie tajemnicy krzyża. W jej życiu cierpienie wyznaczyło kierunek podjętej misji, stało się impulsem i drogowskazem do realizacji życiowego powołania. Przygodność doświadczona namacalnie pozwoliła odkryć sens i cel życia. Matka Czacka miała pełną świadomość, że jedynie religia Krzyża i Zmartwychwstania pozwala zrozumieć sens cierpienia, uczy świadomego i twórczego przyjęcia go i czyni z niego narzędzie zwycięstwa nad złem i nad cierpieniem.

Tylko ona daje możność przyjęcia w prawdzie tych ciężarów i tych ograniczeń, które narzuca ślepota, i tylko ona uczy przetwarzać je na wartość pozytywną. Jedynie niewidomy głęboko wierzący, posiadający pełnię życia

32 J. Stabińska, Matka Elżbieta, s. 183.

33 D. Dajmund, Miłość życia hrabianki Czackiej, http://apchor.pl/2013/10/24/Milosc-zycia-hrabianki-Czackiej, dostęp: 3.07.2017.

34 Z. Ryn, Cierpienie ma tysiąc twarzy. Jan Paweł II i chorzy, Kraków 1988, s. 33.

35 Jan Paweł II, List apostolski „Salvifici Doloris”, Kraków 1999, pkt 26.

36 T. Gadacz, O umiejętności życia, Kraków 2003. 
Bożego, nie ugnie się pod ciężarem kalectwa, lecz przyjąwszy je w pełni, przemieni na swoją siłę 37 .

W cierpieniu Matka Elżbieta odnalazła prawdziwą wolność: „Szczęśliwy człowiek, jeżeli wśród bólu, wyzwolony ze wszystkiego, tylko Boga szuka i Jego znajduje. Wtedy wśród cierpienia i bólu zaczyna człowiek nowe życie, życie pełne radości i szczęścia wśród cierpień, bólu i łez"38. Uświadomienie sobie bowiem faktu własnej niewystarczalności i skończoności, własnej ograniczoności, może ukierunkować człowieka ubogiego i cierpiącego ku poszukiwaniu wartości niezmiennych, absolutnych, w których mógłby znaleźć oparcie i sens. „Cierpienie płynące z miłości Bożej, przyjęte przez nas z poddaniem się woli Boga i z miłości ku Niemu, zlewa na duszę pokój i radość, te dwa owoce Ducha Świętego, których świat nie dawa i dać nigdy nie może"39. Dla Matki Czackiej Krzyż stanowił najważniejszą podstawę Jej życia. Obecny był w Jej pracy, podejmowanej działalności, w życiu codziennym, czego wyrazem jest zarówno nazwa założonego przez Matkę Elżbietę zgromadzenia - Franciszkanki Służebnic Krzyża, jak również codzienne ich pozdrowienie: „Przez Krzyż - do Nieba”. Ponadto siostry codziennie w swoich modlitwach wołają: „Caritas Christi urget nos” oraz "Pax et gaudium in Cruce” czyli "Miłość Chrystusa przynagla nas” oraz „Pokój i radość w Krzyżu”. Jest to więc duchowość, która w słabości odkryła najwyższą siłę. W tym zgromadzeniu, którego podstawy wypracowała Matka Czacka, ,życie dokonuje się według wzoru trynitarnego dawania-siebie, gdzie każda strata staje się zyskiem, każde opuszczenie-siebie - odnalezieniem-siebie, oczywiście tylko przez krzyz" ${ }^{\prime 40}$.

Cierpienie, w którym zanurzona była Matka Elżbieta, utwierdzało Ją w przekonaniu, że to ono nadaje życiu prawdziwy sens. Każdy człowiek doświadcza w swojej egzystencji cierpienia, jednak niewielu ludzi traktuje je jako szansę wyzwanie, lekcję cierpliwości, próbę, czy też drogowskaz w swoim życiu. Matka Elżbieta akcentowała, że „Całe życie człowieka jest szkołą cierpienia. Dziwnie mało

37 A. Dzwonnik, Przez krzyż do Nieba..., http://www.sekretariat-misyjny.pl/index. php?option=com_content\&task $=$ view\&id $=840 \& I t e m i d=45$, dostęp: 3.07 .2017 .

38 AFSK, Dyrektorium Zgromadzenia Sióstr Franciszkanek Służebnic Krzyż (c. XXXI, 26 II 1928 - mps).

39 Tamże, (B. I., 3 VIII 1928 - mps).

40 K. Hemmerle, Tezy ontologii trynitarnej, tłum. L. Skolik, Kielce 2003, s. 78-79. 
ludzie korzystają z tej szkoły. Spotyka się czasem ludzi starych, którzy najmniejszej przeciwności znieść nie umieją, bywa nawet, że uważają się za pobożnych" ${ }^{\prime 11}$.

Cierpienie i choroba są nieodłączną częścią człowieka. Sens cierpienia nie jest łatwy do zrozumienia w życiu od narodzin do naturalnej śmierci. Wydaje być się absurdem, zbędnym balastem, całkowicie nieczytelnym i niemożliwym do zrozumienia ${ }^{42}$. Takie osoby jak Matka Elżbieta Róża Czacka odsłaniają inne spojrzenie na cierpienie, pokazują, że słabość jest twórczym składnikiem ludzkiego życia. Taką postawą akcentują, że każda osoba jest wezwana do odkrywania wartości cierpienia obecnego w świecie, by wyzwalać miłość, a dzięki niej przekształcać całą cywilizację ludzką w cywilizację miłości ${ }^{43}$. W swoich zapiskach wielokrotnie podkreślała, że człowiek poznaje siebie w pełni wyłącznie na drodze cierpienia. Innej drogi nie ma. Przeżywane najbardziej trudne sytuacje pozwalają nam odkryć nasze człowieczeństwo.

Szczęśliwy człowiek, który umie przyjąć cierpienie w całej nagości wprost od Boga. Takie cierpienie bez żadnych domieszek własnych trwa tak długo, jak się Bogu podoba, Tak długo trwa, aż się oczyści i wypali to, co Bogu w duszy przeszkadza, co hamuje swobodę Ducha św. w duszy. [...] Nikt siebie nie zna, dopóki nie cierpia ${ }^{44}$.

W swoich Notatkach zapisała znamienne słowa: „Gdyby mi dano do wyboru, wybrałabym raczej ślepotę fizyczną niż tę, która unieszczęśliwia człowieka na całą wieczność" ${ }^{45}$. W cierpieniu, przeżywanym kalectwie, a zatem w swej bytowej kruchości, Matka Czacka odkryła najwyższe pokłady swej siły. Ta droga naznaczona niebywałym cierpieniem pozwoliła zrozumieć własne człowieczeństwo oraz odkryć sens Jej życia.

Matka Elżbieta Czacka swoje kalectwo przyjęła jako wyjątkowy dar Boży i znak osobistego powołania życiowego. Pokonując swój osobisty dramat,

41 AFSK, Dyrektorium Zgromadzenia Sióstr Franciszkanek Służebnic Krzyż (c. XXII, 3 III 1928 - mps).

42 J. Brusiło, Prawo do śmierci. Życie czy wolność, w: Etyka wobec współczesnych dylematów, red. K. Kalka, A. Papuziński, Bydgoszcz 2006, s. 176.

43 Jan Paweł II, Salvifici Doloris, nr 30.

44 AFSK, Dyrektorium Zgromadzenia sióstr franciszkanek służebnic Krzyża (c. XXXII, 3 III $1928-\mathrm{mps})$.

45 AFSK, Matka Elżbieta Czacka, Konferencje duchowe dla sióstr (Notatki), mps. 
zyskała niespotykaną mądrość serca, która z kolei pozwoliła jej koncentrować się nie na sobie, ale poświęcić życie innym. Jej niemoc stała się swoistą siłą napędową do podjęcia wielkiego Dzieła, jakim była służba niewidomym.

Powyższe analizy potwierdzają, że osoby zmagające się każdego dnia z cierpieniem, obdarzone są bogactwem autentycznych wartości. Dlatego rodzice, nauczyciele, wychowawcy, powinni być przygotowywani do tworzenia takich warunków rozwoju intelektualnego, etycznego, emocjonalnego dla wychowanka, które czyniłyby życie każdego człowieka, zwłaszcza cierpiącego, szczególną wartością. W wychowaniu do właściwego przeżywania kruchości ludzkiej egzystencji istotna rola spoczywa na wychowawcy, który zobowiązany jest pomagać w rozwijaniu postaw prospołecznych, dalekich od umiłowania wyłącznie siebie i zdobywania wszystkiego wyłącznie dla siebie. Ponadto, zarówno rodzina, jak i szkoła winny uwrażliwiać od najmłodszych lat na wartość każdej osoby ludzkiej, podmiotowego jej traktowania i respektowania jej głębokiej własności ontycznej, którą stanowi godność osobowa.

Streszczenie: W niniejszym artykule została podjęta próba ukazania sensu cierpienia w życiu człowieka na przykładzie życia Matki Elżbiety Róży Czackiej (1876-1961). Każdy człowiek stanowi kruchą egzystencję, jest istotą słabą. Nie ma człowieka, który byłby idealny, w każdej sferze życia doskonały, zawsze sprawny, zdolny podejmować nieograniczone niczym wyzwania. Brakowość i ograniczenie, są to zatem cechy, które odnajduje w sobie każdy byt ludzki. Osoby z niepełnosprawnością, chore i cierpiące, żyjące w trudzie, bólu w sposób szczególny przypominają nam o naszej ludzkiej ograniczoności. Wiele z nich swoją postawą uczy, że słabość jest twórczym składnikiem ludzkiego życia. Przykładem takiego przeżywania niepełnosprawności jest Matka Czacka, która odnalazła sens swojego istnienia w cierpieniu, poświęcając swoje życie innym. Swoje kalectwo przyjęła jako zadanie i powołanie życiowe, otrzymane od samego Boga.

Słowa klucze: cierpienie, niepełnosprawność, przygodność, rozwój osobowy

\section{Bibliografia}

Archiwum Franciszkanek Służebnic Krzyża:

- Dyrektorium Zgromadzenia Sióstr Franciszkanek Służebnic Krzyż (mps).

- Matka Elżbieta Czacka, Konferencje duchowe dla sióstr (Notatki), mps.

- Notatki osobiste pisane na życzenie ojca Władysława Korniłowicza, 1927-1934 (14 IX 1927 - mps). 
Bartoszek A., Niepełnosprawność osób jako wyzwanie moralne, w: Osoby niepełnosprawne w życiu Kościoła i społeczeństwa, red. A. tenże, D. Sitko, Katowice-Ruda Śląska 2003, s. 63-89;

Brusiło J., Prawo do śmierci. Życie czy wolność, w: Etyka wobec współczesnych dylematów, red. K. Kalka, A. Papuziński, Bydgoszcz 2006, s. 172-184.

Chudy W., Powołanie osoby niepełnosprawnej w nauczaniu papieża Jana Pawła II, w: Osoba niepełnosprawna i jej miejsce w społeczeństwie, red. D. Kornas-Biela, Lublin 1988, s. 123-149.

Chudy W., Sens filozoficzny kondycji człowieka niepełnosprawnego, w: Osoba niepełnosprawna i jej miejsce w społeczeństwie, red. D. Kornas-Biela, Lublin 1988, s. 105-122.

Chudy W., Sens życia a sens trudu, w: Osoby niepelnosprawne $w \dot{z} y c i u$ społeczeństwa i Kościoła, Katowice-Ruda Śląska 2003, s. 31-45.

Chudy, W łupinie orzecha, czyli filozofia bez przesady, Marki-Struga 1992.

Dajmund D., Miłość życia hrabianki Czackiej, http://apchor.pl/2013/10/24/Milosc-zycia-hrabianki-Czackiej, dostęp: 3.07.2017.

Dzwonnik A., Przez krzyż do Nieba..., http://www.sekretariat-misyjny.pl/index.php?option=com_content\&task=view\&id=840\&Itemid=45, dostęp: 3.07.2017.

Gadacz T., O umiejętności życia, Kraków 2003.

Hemmerle K., Tezy ontologii trynitarnej, tłum. L. Skolik, Kielce 2003.

Jan Paweł II, Byłem upośledzony i przyszliście mi z pomoca, Osnabruck 16. XI. 1980, Anioł Pański, „L' Osservatore Romano”, 1980, 31 (11), s. 4.

Jan Paweł II, List apostolski „Salvifici Doloris”, Kraków 1999.

Kuczyńska-Kwapisz J., Wkład Matki Elżbiety Róży Czackiej w rozwój tyflologii w kontekście współczesnej recepcji jej myśli, Warszawa 2011.

Naumiuk T., Duch miłosierdzia w życiu sługi Bożej matki Elżbiety Róży Czackiej, „Brat”, 2016, nr 11, s. 10-11.

Notatki Osobiste pisane na życzenie Ojca Władysława Korniłowicza, 1927-1934 (mps).

Pascal B., Myśli, tłum. T. Żeleński (Boy), Warszawa 1989.

Rodziński A., Na orbitach wartości, Lublin 1998.

Ryn Z., Cierpienie ma tysiąc twarzy. Jan Paweł II i chorzy, Kraków 1988.

Spaemann R., Osoby. O różnicy między czymś a kimś, tłum. J. Merecki, Warszawa 2001.

Stabińska J., Matka Elżbieta Róża Czacka, Laski 1986.

Szarkowicz D., Osoby niepełnosprawne w społeczeństwie. Integracja czy zagrożenie wykluczeniem?, w: Marginalizacja w problematyce pedagogiki społecznej i praktyce pracy socjalnej, red. K. Marzec-Holka, Bydgoszcz 2005, s. 63-90.

Szostek A., Wokół godności, prawdy i miłości, Lublin 1998.

Wojtyła K., Osoba i czyn oraz inne studia antropologiczne, Lublin 1994. 